\title{
PORTRÉ
}

\section{Somssich Gabriella}

A portré elnevezésű rovat most először jelenik meg új folyóirati müfajként a Belügyi Szemlében. E rovatban a belügyi, rendvédelmi szak- és tudományterületek kimagasló teljesítményt nyújtó szakembereiről készített portré-jellegü írások olvashatók majd rendszeresen. Szándékunk szerint nem életrajzi portrékat, hanem olyan szakmai jellegü portrékat kívánunk közzétenni, amelyek a portréalany szakmai eredményeiről, szakmai sikereiről szólnak. Arra törekszünk, hogy a portréalanynak a gyakorolt szakmájához való viszonyulása rajzolódjék ki írásainkban, és az olvasó elsősorban arra kapjon választ, hogy portréalanyaink mit adtak és kaptak a választott hivatásuktól, milyen eredetủ motivációk vezették el őket a sikerhez. E portrékban a személyesség mozzanatát tartjuk a legfontosabb elemnek, de mindezt a szakmai oldal hangsúlyozásával kívánjuk bemutatni.

Április havi lapszámunkban Magyarország első kinevezett női megyei rendőrfőkkapitányáról, dr. Somssich Gabriella r. dandártábornok asszonyról, a Nógrád Megyei Rendőr-főkapitányság vezetőjéről készült portrénkat olvashatják, amelyet Hornyik Zsuzsanna készített.

Dr. Somssich Gabriella r. dandártábornok asszony - ahogyan azt már több interjúban is elmondta - mindig is rendőr szeretett volna lenni. A hivatásáról olyan magával ragadó módon, lelkesítően, rajongással telve tud beszélni a mai napig, amely irigylésre méltó. Vajon mi vezetett ehhez a megingathatatlan elképzeléséhez, életcéljához? Hisszük, hogy mindenki életében van egy meghatározó személy, egy meghatározó pillanat, amely eldönti, hogy milyen irányba veszi útját az élete. Természetesen az sem mindegy, hogy milyen beállítottságú az ember, milyen belső tulajdonságokkal rendelkezik, milyen kompetenciák birtokában van, és a későbbiek során milyen helyzetekben kell helytállnia. Magyarország első női rendőrfőkkapitányának személyében egy olyan embert ismerhetünk meg, aki már iskolás korától kezdve nagyon tudatosan készült későbbi hivatására, és még a jogi egyetem elvégzése - amelyre szülei talán a rendőri pályától való eltérítés szándékával biztatták - sem tudta megmásítani eredeti tervét, inkább hozzájárult a választott élethivatás alapos előkészítéséhez. Nógrád megye rendőrfőkapitánya olyan ember, aki mindig belső indíttatásból törekedett arra, hogy minden téren maradéktalanul megfeleljen mind a tanulmányok elvégzése, mind a szakmai kihívások, mind pedig az elvégzendő 
feladatok, megoldandó ügyek tekintetében. Tényleges harmincévnyi szolgálati jogviszonnyal a háta mögött, kétséget kizáróan öszintén állítja, hogy mindennel együtt örömként élte meg pályafutásának minden percét. Férje sokat hangoztatott kijelentése is ezt támasztja alá, miszerint felesége számára ő az egyik szerelem, a másik a rendőri hivatás.

A kezdetek. Komlón, Baranya megyében született, itt is járt általános iskolába és középiskolába. Egy osztálytalálkozón az osztályfőnök felolvasta azokat a jellemzéseket, amelyek a legelső években készültek a gyerekekről. Már ebből kitünt a túlfejlett igazságérzet, amely - az értő pedagógus észrevétele szerint - előrevetítette annak valószínüségét, hogy mindenképpen a jogi, rendészeti pályán, vagy a közigazgatás más területén fog dolgozni. Bár egy időben az ifjúságvédelem területe is csábította, de ez sem tántorította el eredeti elképzelésétől. Az iskolában tartott rendhagyó, rendőrséget bemutató osztályfőnöki órák, amelyet a komlói rendőrkapitányság munkatársai tartottak, szintén nagy hatással voltak rá. Érdekes módon tíz évvel idősebb bátyja, aki szintén a rendőrségnél dolgozott, nem orientálta különösképpen a pálya felé. Szülei a kezdetektöl fogva féltették, de mindig is azt szerették volna, hogy lányuk becsületes, tisztességes ember legyen és megtalálja a boldogságot a hivatásában, ki tudjon teljesedni benne.

Félúton. A pécsi jogi karon nappali tagozatos hallgatóként folytatta tanulmányait. Szerencséjének tartja, hogy jó évfolyamtársak, inspiráló oktatók, professzorok vették körül. Kedvenc tantárgya a büntetöjog volt, szakdolgozatát Földvári József professzorhoz írta, és az egyetemi évek alatt számtalan bírósági tárgyaláson vett részt, hogy az elméleti tudását gyakorlati tapasztalatokkal is elmélyítse. Több ügyész, bíró látta volna szívesen kollégái sorában, de nem tudták elcsábítani a rendőri pályától. Harmadévesként pedig, miután belügyi ösztöndíjas lett, a Baranya Megyei Rendőr-főkapitányságon vett részt nyári gyakorlatokon, azon az osztályon, ahol gyilkossági ügyekben is nyomoztak. Bünügyi technika oktatásra is rengeteget járt. Az egyetem elvégzése után a Pécsi Rendőrkapitányság Vizsgálati Osztályán kezdett dolgozni, ahol kezdetekben - a már meglévő elméleti tudásra alapozva - a gyakorlati tudás megszerzésén volt a hangsúly, hiszen azt, hogy miként zajlik egy kihallgatás, illetve hogyan néz ki egy ügyirat, itt tudta megismerni, elsajátítani. A Pécsi Rendőrkapitányság Vizsgálati Osztályáról állomásra (később rendőrőrs) került a kertvárosba bünügyi helyettesi beosztásba, egy igazán jó csapattal. Számára mindig is fontos volt a csapat, hiszen a rendőrség tevékenysége során elért eredményei nem egy-egy ember sikerei, és azt is teljes bizonyossággal állítja, hogy csak az ér el sikereket, aki tesz is érte. Igencsak sok munka jellemezte ezt az időszakot, amelynek során sokat tanult a szakmáról és a kollégáktól egyaránt. Innen a Baranya Megyei Rendőr-főkapitányság Közlekedési Osztálya Közlekedésbiztonsági Alosztályára 
került, fővizsgálóként dolgozott egy rövid ideig, közben az átképzőt végezte Budapesten. Ezzel egy időben jogi szakvizsgázott, mert ezt is fontosnak tartotta. Az átképző végzése során megkeresték a Baranya Megyei Rendőr-főkapitányság részéről, hogy nem menne-e át a Bünügyi Osztályra, oda, ahol annak idején ösztöndíjasként a gyakorlatát töltötte. Oda, ahová abban az időben nőket nem vettek fel, vele mégis kivételt tettek. Itt végigjárta a ranglétrát, elmondása szerint mind emberileg, mind szakmailag ezek az évek nagyon meghatározók voltak számára, ez az időszak segítette igazán hozzá a szakmai értelemben vett felnőtté váláshoz. A mai napig ezt tartja szakmai pályája egyik csúcsának. Életes nyomozóként számos nehézséggel, megrázó emberi sorssal találkozott, de mindenből tanult. Legfőbb irányelv az volt, hogy a sértettek, áldozatok érdekeit szem elött tartva mindent meg kellett tenni azért, hogy az elkövetök felderítésre kerüljenek. Nagyon fontos megemlíteni, hogy a rendkívüli haláleseteknél dolgozó kollégáknak - nem csak a rendőröknek, más szervek munkatársainak is - mindenképpen függetlenítenie kell magukat a konkrét ügytől. Ezeket nem szabad hazavinni, a kollégákkal kell megbeszélni, ezért fontos, hogy olyan legyen a munkahelyi közösség, ahol észreveszik, ha valakit jobban megvisel egy-egy eset. Számára a nyugodt családi háttér, a zene szeretete, az élménnyel teli utazások, a folytonos tanulás és a megértő kollégák biztosították azt, hogy valóban függetleníteni tudta magát az ügyektől.

Az előre lépés útján. A Baranya Megyei Rendőr-fơkapitányságon töltött évek után szakmai életútja újabb állomáshoz érkezett. A Rendvédelmi Szervek Védelmi Szolgálatához került, s következő beosztásaihoz - Igazságügyi és Rendészeti Minisztérium Rendészeti Felügyeleti és Ellenőrzési Főosztály vezetője, ORFK Ellenőrzési Szolgálat vezetője -szüksége volt jól fejlett igazságérzetére a korrupció ellenes tevékenység során, amelyből jogászként is kivette a részét, ugyanis a területre vonatkozó jogszabályokat előkészítő munkacsoport tagja, majd vezetője lett.

Szerencsésnek tartja magát, mert valamennyi munkahelyén olyan kollégákat ismert meg, akik közül sokakkal a mai napig tartja a kapcsolatot. A közösségformálás terén fontosnak tartja a bizalmat, mindenki számára elérhető igyekszik lenni. Olyan vezető, aki nyitott a beosztottak egyéni problémáira, mindent igyekszik megköszönni, fontosnak tartja a folyamatos visszajelzést a munkatársak felé. Nem véletlen, hogy vezetői kompetenciái közül a munkatársak motiválása magaslik ki leginkább a kiválasztási szakértők szerint is. Nagyon sokat számítanak a közösségi események, ünneplések, az egyéni elismeréseknek is a legjobb, ha együtt örül a közösség. A közösségért mindenkinek tennie kell, ettől válik csapattá, amely képes az állomány megtartására is, mert óriási töltést tud adni egy jó közösség. Vezetőként mindig azt tartotta fontosnak, hogy olyan 
munkahelyi körülményeket teremtsen maga körül, ahol mindenki jól érzi magát. Ebben nagy szerepet játszik a személyes példamutatás is, amely szintén egyik erősségének mondható, és amely kifejezi a szervezet iránti lojalitását és elkötelezettségét. A következetesség, kiszámíthatóság mindenki számára biztonságot jelent hitvallása szerint. Ha valaki segítségre szorul, fontos, hogy merjen kérdezni, és ehhez az kell, hogy meglegyen a bizalom, a nyíltság, mert mindig akadnak problémák, amelyeket ezek megléte esetén lehet csak megoldani. Nagy segítség ezekben a helyzetekben a konfliktuskezelési képesség, amelynek ugyancsak birtokában van, és amelynek köszönhetően képes a változó helyzeteket megfelelően kezelni. Szereti a kreatív, okos munkatársakat maga körül, akikkel tényleg csapatban lehet együtt dolgozni, és szerencséjének tartja, hogy szakmai életútja során szinte mindig ilyen kollégákkal dolgozott.

Az elért szakmai eredmények tekintetében nem emelne ki egyet sem, mert valamennyit ugyanolyan fontosnak tartja. Maradtak le nem zárt emberölési ügyek, akadtak utólag felderített bünesetek, de úgy érzi, mindegyik kapcsán újabb ismeretekre tett szert. Olyan pozitív személyiség, aki még a befejezetlen ügyekkel szembesülve is átlendült a nehézségeken, mert hozzáállásával mindig azt nézte, hogy miből mit lehet tanulni, értékes tapasztalatokat szerezni.

Személyes, szakmai erősségének tekinti, hogy tudatosan, jól választott hivatást. Mindig is rendőr akart lenni. Mindig céltudatos, lényeglátó hozzáállás jellemezte. A jogi egyetemen megszerzett tudás, annak gyakorlatba átültetése segítette hozzá ahhoz, hogy a jogértelmezésben magabiztosan mozogjon és ez rendőri munkáját is segítette. Az átképzőn mindösszesen öten voltak bünügyesek, így nem is klasszikus értelemben vett előadásokat hallgattak a csoporttársakkal, hanem igazi gyakorlati tudást adó foglalkozásokon vettek részt, amelynek köszönhetően olyan szakmai munícióval vértezték fel ezek az évek, amelyek a mai napig segítik a munkájában. Ez a képzés biztos alapot nyújtott a szakmához, s örökérvényü szakmai fortélyokra tett szert. A folytonos tanulás, képzés szükségességét hangsúlyozza, mert a fejlődés nem áll meg. Az élethosszig tartó tanulást nem lehet kiváltani, és ebben igazi példaképként jár elől, mint ahogyan a reális önismeretben is, hiszen szakmai életútját tekintve valóban mindig csak testhezálló feladatot, felkérést vállalt el.

Napjainkban. Jövőbeli terveit illetően nem gondolt korábban a jelenlegi beosztására irányuló felkérésre. Nagy megtiszteltetésként és elismerésként tekint rá, azt a családjától kapott teljes mértékü támogatás birtokában fogadta el, amelyen kívül további erőt adott a feladat megkezdéséhez a teljes állomány támogatása, nemcsak Nógrád megyében. Olyan sok pozitív visszajelzést kap a kollégáktól, kiemelten a női kollégáktól, amelyért nem győz eléggé hálás lenni. Bármerre jár, még mindig kapja a gratulációkat és azt a megerősítést, hogy az ő példája 
szolgál bizonyságul arra, hogy nem szabad feladni, a rendőri pályán igenis meg lehet valósítani az álmokat, mindazzal együtt, hogy nem lesz mindenkiből rendőrfőkkapitány, de ha becsületesen, szabálykövetően végezzük a munkánkat, folyamatosan képezzük magunkat, minden lehetséges. Büszke arra, amit elért, de nem tudta volna elérni a családja támogatása nélkül, a mellette álló kollégák nélkül, akikkel mindig igyekeztek a legtöbbet kihozni egymásból.

A megvalósítandó terveket, jövőbeli célkitüzéseket tekintve úgy érzi, hogy egy nagyon jól müködő főkapitányságra került, és belügyminiszter úrtól vett idézettel élve - „Mindent lehet még jobban csinálni.” - készen áll az elötte álló feladatok végrehajtására. Konkrét célja a biztonság megtartása Nógrád megyében, hogy az állampolgárok valóban érezzék mindennapjaik során annak meglétét, hiszen a biztonságérzet mindennek az alapja.

Szeretne rászolgálni a kapott bizalomra. Az állomány fiatal tagjai felé megfogalmazott üzenete, hogy érdemes elhivatottan gyakorolni a rendőri szakmát, mert rengeteg sikerélményt és örömet tud adni. Dr. Somssich Gabriella szakmai életútja követendő példa minden felnövekvő nemzedéknek, igazi megerősítésként szolgál a rendôri állomány valamennyi tagja számára. 